\title{
Identification of Immunodominant Outer Membrane Proteins of Fusobacterium necrophorum from Severe Ovine Footrot By MALDI-TOF Mass Spectrometry
}

\author{
S. Farooq ${ }^{1}$ (I) S. A. Wani ${ }^{1} \cdot$ S. Qureshi ${ }^{1} \cdot$ M. A. Bhat ${ }^{1} \cdot$ Z. A. Kashoo $^{1} \cdot$ I. Hussain $^{1}$
}

Received: 6 October 2020 / Accepted: 5 February 2021 / Published online: 27 February 2021

(c) The Author(s) 2021

\begin{abstract}
The aim of this study was to identify the immunodominant outer membrane proteins (OMPs) of Fusobacterium necrophorum from sheep affected with severe foot-rot. The OMP profile of ovine strains of $F$. necrophorum has not been well studied. We analyzed the OMP profile of the most frequent $l k t A$ variant JKS-F3 of $F$. necrophorum associated with severe ovine foot-rot with lesion score 4 in order to identify its major immunodominant OMPs. Electrophoretic separations of extracted OMPs showed a number of spots in two-dimensional electrophoretic gels. Two immunoreactive proteins of size around $43 \mathrm{kDa}$ were identified through western blotting using hyperimmune sera raised in rabbits. These two immunogenic OMPs were analyzed by Matrix-assisted laser desorption/ionization time-of-flight mass spectrometry (MALDI-ToF/MS) which revealed that these two OMPs of $l k t A$ variant JKS-F3 of $F$. necrophorum showed 46 and 42 percent protein sequence coverage and scores of 125 and 114, respectively, with the reported $43 \mathrm{kDa}$ outer membrane protein of $F$. necrophorum strain H05, a putative porin having properties similar to pore-forming proteins of anaerobic Gram-negative bacteria. These identified immunogenic OMPs will contribute to our understanding of the pathogenic role played by this organism in ovine foot-rot and could be exploited to devise an effective control strategy through development of an OMP-based recombinant vaccine to mitigate foot-rot in sheep and goats.
\end{abstract}

\section{Introduction}

Fusobacterium necrophorum is a Gram-negative, rodshaped, non-spore-forming anaerobic bacterium that is associated with a variety of severe and fatal diseases in cattles, sheep and humans. In humans, F. necrophorum cause Lemierre syndrome, which begins as pharyngitis and rapidly progresses to septic thrombophlebitis of the jugular vein [1]. There are two main subspecies of $F$. necrophorum - ssp. necrophorum (Fnn-biotype A) and ssp. fundiliforme (Fnfbiotype B), and they differ in morphological, physiological and antigenic characteristics. Fnf is mostly implicated in human infection while Fnn being the principal animal pathogen mainly responsible for hepatic abscesses in beef cattle [2-4] and severe foot-rot in sheep and goats along with

S. Farooq

shaheen_mvsc@yahoo.co.in

1 Anaerobic Bacteriology Laboratory, Division of Veterinary Microbiology and Immunology, SKUAST-K, Shuhama (Alusteng), Srinagar, Jammu and Kashmir 190006, India
Dichelobacter nodosus [5, 6]. These anaerobes are more commonly detected in footrot affected than in healthy feet of sheep; hence, both need to be considered when managing a footrot outbreak [7].

Footrot begins as an inflammation of the interdigital skin of sheep and may progress to separation of hoof from the underlying soft tissues. The disease is an infectious syndrome, which is caused by the synergistic action of several bacterial species, particularly $D$. nodosus and $F$. necrophorum $[8,9]$. F. necrophorum is an important pathogen contributing to the severity and duration of severe footrot (SFR) in sheep and goats and is often found in association with $D$. nodosus in infected feet with lesion score of mostly 4 [5, $6,10]$.

Outer-membrane proteins (OMPs) of Gram-negative bacteria are integral proteins which assume a $\beta$-barrel architecture in the outer membrane and are arranged in an antiparallel pattern. OMPs are exposed to the outside of the bacterial cell and are the first line of contact between bacteria and its surroundings [11]. OMPs play many pivotal roles in pathogenesis, resistance and disease development by acting as a dynamic interface between the cell and its surroundings, 
maintenance of cell structure, involved in passive and active transport, adhesion to other cells, binding a variety of substances and antimicrobial resistance [12-14]. A $42.4 \mathrm{kDa}$ outer membrane protein (FomA) of $F . n$ ssp. necrophorum has been characterized and acts as an adhesin for strong binding to host cells, which is a key step in the disease pathogenesis [15]. However, at present there is no comprehensive information regarding the outer membrane proteins (OMPs) of $F$. necrophorum implicated in severe ovine footrot. Given the lack of information on the OMP profile of ovine strains of $F$. necrophorum, we identified and analyzed the OMPs of most predominant $l k t A$ variant JKS-F3 of $F$. necrophorum associated with severe foot-rot lesions in sheep by MALDI-ToF mass spectrometry. This information will further help in understanding the pathogenic mechanism of F. necrophorum in ovine footrot and adds to the list of target antigens that could be exploited for the development of an OMP-based recombinant vaccine to mitigate the severity of footrot lesions.

\section{Material and Methods}

\section{Bacterial Culture and Identification of IktA-Variant JKS-F3}

Fusobacterium necrophorum lktA variant JKS-F3 was used in this study which is the most frequent variant $(86.0 \%)$ detected in severe footrot-affected sheep with lesion scores of mostly 4 [6]. This variant was grown anaerobically on Brain-Heart-Infusion-Blood-Agar (BHIBA, Difco) containing $10 \%$ sheep blood, $0.5 \%$ yeast extract, $0.01 \%$ magnesium sulphate and antimicrobials, vancomycin and neomycin at 5 and $100 \mu \mathrm{g} / \mathrm{ml}$ of media, respectively. For large scale growth, isolated colonies of this variant were inoculated into freshly prepared $200 \mathrm{ml}$ of BHI-broth containing all the above ingredients except sheep blood. The BHI-broth was then incubated anaerobically in a 1.5 liter anaerobic jar (Oxoid, UK) with AnaeroGaspack (Becton and Dickinson, Maryland, USA) at $37{ }^{\circ} \mathrm{C}$ for $48-72 \mathrm{~h}$. The bacterial cells were pelleted by centrifugation at $6000 \times g$ for $20 \mathrm{~min}$.

\section{DNA Etraction and Detection of IktA Gene Fragment}

Few isolated colonies with characteristic morphology were directly suspended into $100 \mu \mathrm{l}$ of nuclease free water in $1.5 \mathrm{ml}$ microcentrifuge tubes and bacterial suspension was made by gentle vortexing. The suspension was boiled for $5 \mathrm{~min}$, cooled on ice for $10 \mathrm{~min}$ and centrifuged at $10,000 \times \mathrm{g}$ for $1 \mathrm{~min}$. Two microlitres of the supernatant were used as the template for the PCR reaction. The DNA extract was subjected to the leukotoxin $(l k t A)$ gene-specific PCR for confirmation of variant JKS-F3 of $F$. necrophorum as detailed by
[16]. The leukotoxin is the major virulence factor encoded by $l k t A$ gene of tricistronic leukotoxin operon $(l k t B A C)$ of $F$. necrophorum. The PCR conditions for amplification of $l k t A$ gene fragment consisted of initial denaturation at $94{ }^{\circ} \mathrm{C}$ for 4 min, followed by 35 cycles of $94{ }^{\circ} \mathrm{C}$ for $30 \mathrm{~s}, 60{ }^{\circ} \mathrm{C}$ for $30 \mathrm{~s}$ and $72^{\circ} \mathrm{C}$ for $40 \mathrm{~s}$. This was followed by final extension of $5 \mathrm{~min}$ at $72{ }^{\circ} \mathrm{C}$. The DNA from $F$. necrophorum strain, which was isolated from severe ovine footrot and confirmed by DNA sequencing of its $l k t A$ gene fragment, served as positive control.

\section{Raising of Hyperimmune Sera in Rabbits}

\section{Preparation of Antigen}

The JKS-F3 lktA variant was grown in BHI-broth as described. The bacterial cells were harvested and washed in PBS solution ( $\mathrm{pH} 7.4$ ) and killed with $0.15 \%$ formalin. To raise hyperimmune sera, approximately $10^{8}$ cells per dose per rabbit was used for immunization [17]. The density of the bacterial suspension was determined by matching it with turbidity standard (McFarland's nephelometer).

\section{Immunization of Rabbits}

A New Zealand white rabbit of $1.5 \mathrm{~kg}$ weight was selected for immunization, and two doses 30 days apart were given. Prior to immunization, $2 \mathrm{ml}$ of blood was collected to get the pre-immune sera. The first dose of antigen was prepared in Complete Freund's Adjuvant in the ratio of 1:1 in a volume of $0.5 \mathrm{ml}$. The emulsion was prepared with the help of a syringe and a 18 gauge needle. The first dose was administered at four different sites subcutaneously, at $0.1 \mathrm{ml}$ per site. The booster dose was prepared in a similar way but in Incomplete Freund's Adjuvant. The blood was then collected at 7, 10, 14 and 21 days after the booster dose and the serum was separated. The antibody titer of the sera was checked through a micro-plate agglutination test, and the serum with high antibody titer was stored in aliquots at $-80{ }^{\circ} \mathrm{C}$ until use.

\section{Extraction of OMPs}

For extraction of the OMPs, the bacterial cells were grown in bulk in BHI-broth as described above, harvested and washed in PBS. The harvested cells were suspended in $10 \mathrm{ml}$ of 0.01 M HEPES buffer ( $\mathrm{pH} 7.4$ ), protease inhibitor cocktail was added to the suspension, which was subjected to ultrasonication in an ice-water at $30 \%$ amplitude with 15 pulses on/off of $59 \mathrm{~s}$ each. The sonicated cells were subjected to centrifugation at $17,000 \times g$ for 20 min to pellet the cell debris. The supernatant obtained was subjected to ultracentrifugation at $230,000 \times \mathrm{g}$ for $70 \mathrm{~min}$ to pellet the membrane 
fraction. The pellet thus obtained was dissolved in $10 \mathrm{ml}$ of $2 \%$ sodium sarcosinate in 0.01 M HEPES buffer ( $\mathrm{pH} 7.4$ ), incubated at room temperature for $60 \mathrm{~min}$ with gentle agitation and subjected to ultracentrifugation at $125,000 \times g$ for $110 \mathrm{~min}$ to get the pellet of OMPs. The pellet containing the OMPs was dissolved in $300-500 \mu \mathrm{l}$ of sterile double distilled water and stored at $-80{ }^{\circ} \mathrm{C}$ until use.

\section{Estimation and Ceaning Up of OMPs for 2-Dimensional Electrophoresis (2DE)}

The protein estimation and cleaning up of the samples was performed using the 2-D Quant Kit and 2-D Cleanup Kit (GE Healthcare), respectively, according to the manufacturer's instructions.

For 2DE, briefly,13-cm immobiline DryStrip gels (IPG strip, GE Healthcare) with a $\mathrm{pH}$ range 3-11 were hydrated over night with $250 \mu \mathrm{l}$ of extracted OMPs (600 $\mu \mathrm{g} /$ strip) resuspended in DeStreak rehydration solution in the Immobiline DrySrip re-swelling trays (GE Healthcare) at room temperature. Following complete hydration of the strips, first dimension isoelectric focusing (IEF) was performed in a Ettan IPG phorII (GE Healthcare) with an appropriate software for 3-11 $\mathrm{pH}$ range and 13-cm-long Immobiline DryStrips. After IEF, the IPG strips were equilibrated for the second dimension. The equilibration was performed by first treating strips with dithiothreitol $(100 \mathrm{mg})$ and then with iodoacetamide $(250 \mathrm{mg}$ ) per $10 \mathrm{ml}$ of equilibration buffer separately for $15 \mathrm{~min}$ each with gentle shaking.

After IEF and strip equilibration, SDS-PAGE was performed in an SE 600 Ruby vertical electrophoresis unit (GE Healthcare) using a $12.5 \%$ polyacrylamide gel. The conditions for the runs were: $430 \mathrm{~V}, 120 \mathrm{~mA}$ and $100 \mathrm{~W}$ for two gels loaded simultaneously. After completion of the run, one gel was subjected to staining with Pulse one Coomassie PhastGel Blue R-350 (GE Healthcare) for visualization of OMPs and the other was subjected to western blotting.

\section{Western Blot Aalysis of OMPs with Sra from Rabbit}

The gel from the second-dimension SDS-PAGE was blotted onto polyvinylidene difluoride (PVDF) (Hybond-P, GE Healthcare) membrane for detection of immunoreactive OMPs. The conditions used for transfer were $30 \mathrm{~V}$ maximum, $430 \mathrm{~mA}$ current for about $2 \mathrm{~h}$. After the protein transfer, the PVDF membranes were blocked with 5\% nonfat skimmed milk in PBS at room temperature on a rocker overnight. After washing three times with $0.1 \%$ Tween20 in PBS(PBST) for 10 min each, the PVDF membrane was incubated with primary antibody raised in rabbit (as above) at a dilution of 1:1000 in PBS containing 1\% Bovine Serum Albumin for $1.30 \mathrm{~h}$ at room temperature on a rocker. The membrane was washed in PBST three times, $10 \mathrm{~min}$ each and incubated with secondary antibody (anti-rabbit IgG raised in goat and conjugated with HRPO, Sigma) at a dilution of 1:3000 in PBS for $1.30 \mathrm{~h}$, with gentle shaking on a rocker at room temperature. The membrane was again washed three times with PBST, 10 min each and developed with $0.05 \%$ 3,3'-diaminobenzidine solution until protein spots were visualized.

\section{Identification of Immunoreactive OMPs}

The protein spots (OMPs) from the stained gel corresponding to the developed spots on the PVDF membrane were picked and stored in $8 \%$ acetic acid solution and outsourced for MALDI-TOF/MS analysis for protein identification.

\section{Results}

\section{Isolation and Detection of JKS-F3 IktA Variant of $F$. necrophorum}

After subsequent subculture of JKS-F3 variant on BHIBA containing $10 \%$ sheep blood, pure culture of F. necrophorum was obtained. The colonies on BHIBA appeared as flat, irregular, grayish and surrounded by zone of $\beta$-haemolysis and produced characteristic lipolytic activity on egg yolk agar medium. The lipolytic activity is due to the lipase produced by bacteria that hydrolyze free fat present in the medium to glycerol and free fatty acids. Insoluble free fatty acids results in the development of an iridescent sheen (as with oil on water) that can be seen when the plate is held at an angle to a light source. The Gram-stained smear demonstrated pleomorphic character of $F$. necrophorum. For further confirmation, isolated colonies were subjected to PCR targeting 400 base pair (bp) amplicon, characteristic of the lktA gene fragment of F. necrophorum (Fig. 1).

\section{OMP Profile of JKS-F3 IktA Variant of F. necrophorum}

A number of protein spots ranging from 29 to $54 \mathrm{kDa}$ were visualized following two-dimensional gel electrophoretic separations of OMP extracts of a JKS-F3 $l k t A$ variant of F. necrophorum. Based on the SDS-PAGE analysis, a few protein spots of sizes around $43 \mathrm{kDa}$ were more prominent than the other spots (Fig. 2a). Western blotting revealed only two prominent protein spots (Spot 1 and Spot 2) on the PVDF membrane using primary antibodies raised in rabbit against the JKS-F3 $l k t A$ variant of $F$. necrophorum (Fig. 2b). These two major immunoreactive spots both correspond to molecular weight of around $43 \mathrm{kDa}$ with distinctly separated isoelectric points on the $13 \mathrm{~cm}$ immobiline DryStrip gel with a pH range 3-11. 
Fig. 1 Detection of $l k t A$ gene fragment of variant JKS-F3 of F. necrophorum by polymerase chain reaction. Lane $1=$ Test sample. Lane $2=$ Positive control. Lane $3=$ Negative control. Lane $\mathrm{M}=100$ bp DNA ladder

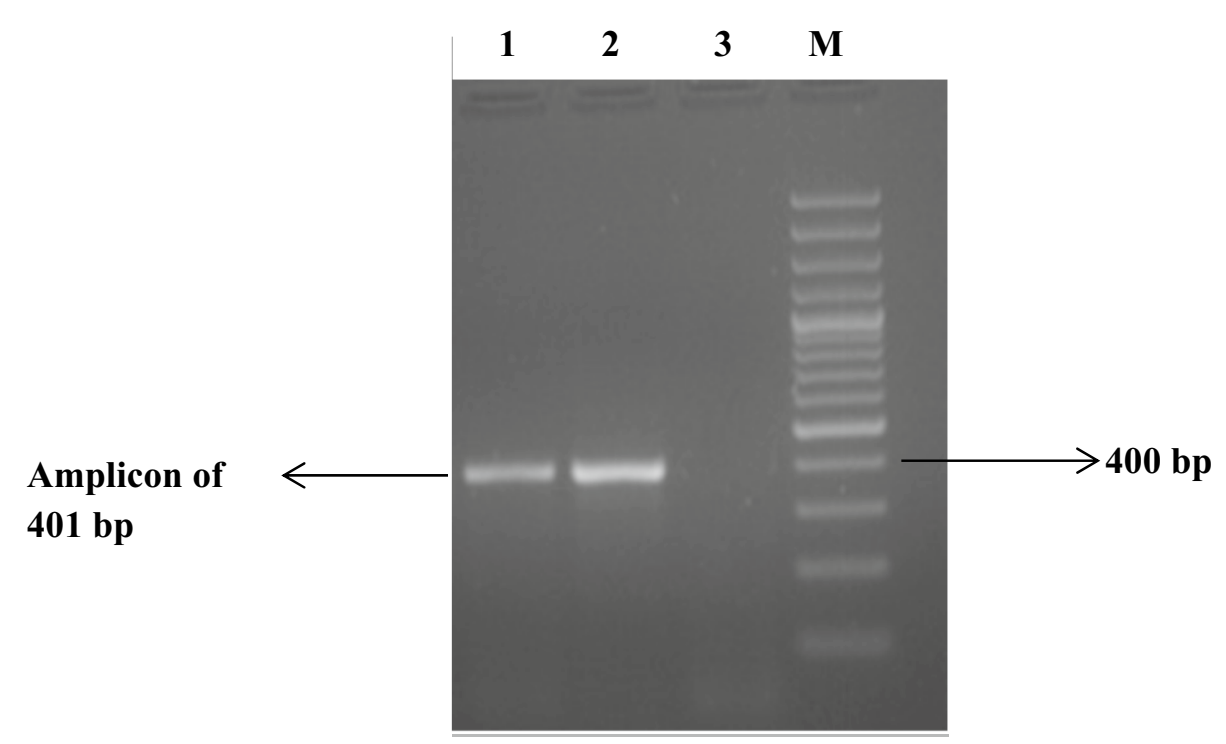

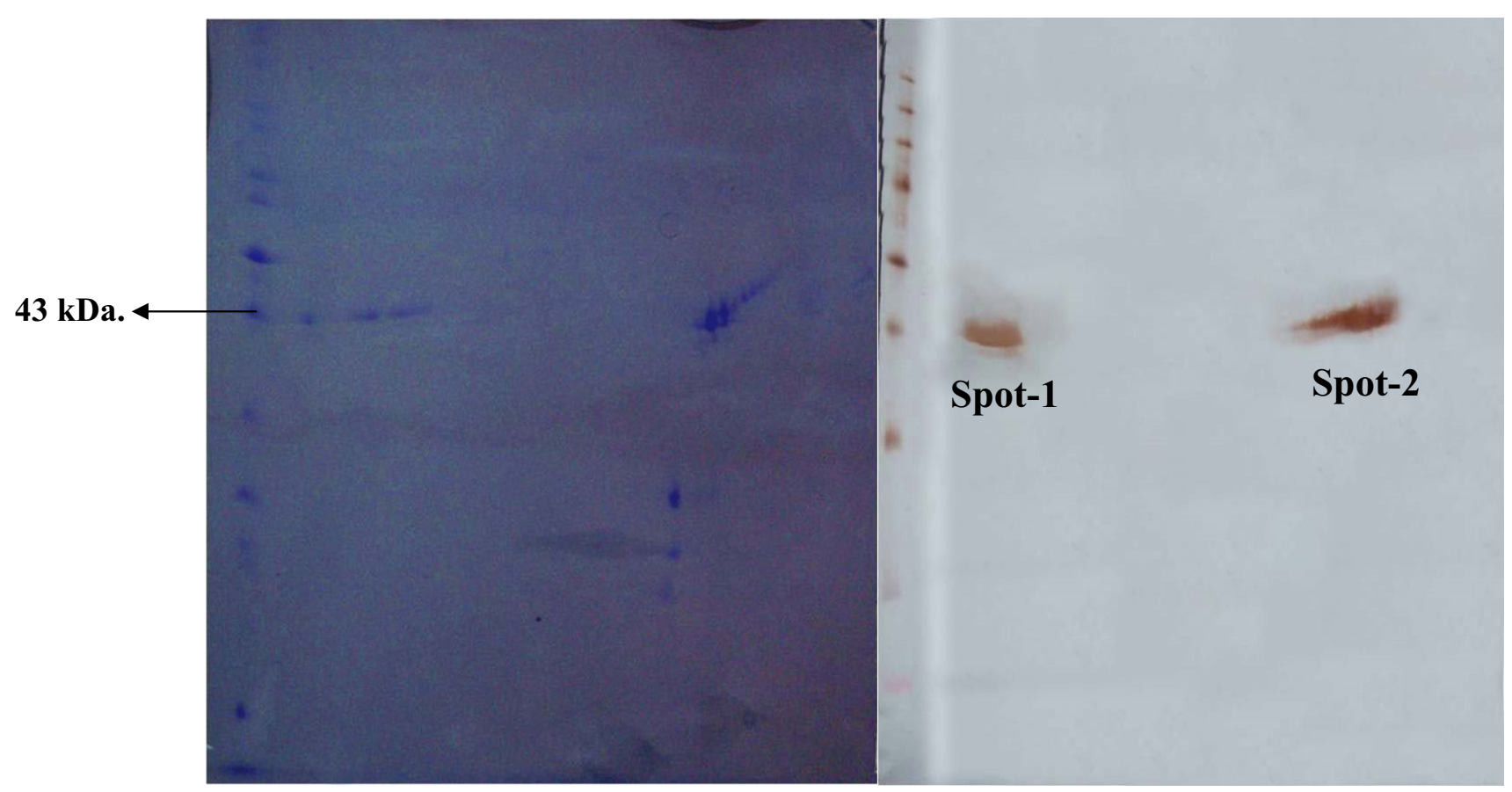

a)

b)

Fig. 2 2DE profile of OMP fraction of variant JKS-F3 of F. necrophorum (a) and its western blot on PVDF membrane (b)

\section{Identification of Immunodominant OMPs of $F$. necrophorum By MALDI-ToF Mass Spectrometry}

The peptide mass fingerprints (PMFs) generated by MALDIToF MS after tryptic digestion of OMPs produced sixteen and fifteen peptides for spots 1 and 2, respectively. The PMF data obtained for these unknown OMPs were analyzed by matching with the PMFs of $F$. necrophorum proteome contained in NCBI protein database using the MASCOT search results. The results depicted top ten protein matches for each OMP along with their accession numbers, mass, protein sequence coverage, score and description. The OMPs obtained from $l k t A$ variant JKS-F3 of $F$. necrophorum showed highest sequence coverage (46 and $42 \%$ ) and scores (125 and 114) with the reported $43 \mathrm{kDa}$ OMP, a putative porin protein of $F$. necrophorum strain $\mathrm{H} 05$ (Accession 
No. AFJ54023.1) (Figs. 3, 4). The protein scores greater than 84 are considered significant with $p$ value $<0.05$. The identified OMPs were homologous with OMP of F. necrophorum strain H05 consisting of 377 amino acid residues.
Its 3D structure was built in ExPASy swiss-model which revealed that its structure resembles porin proteins of outer membrane (Fig. 5).

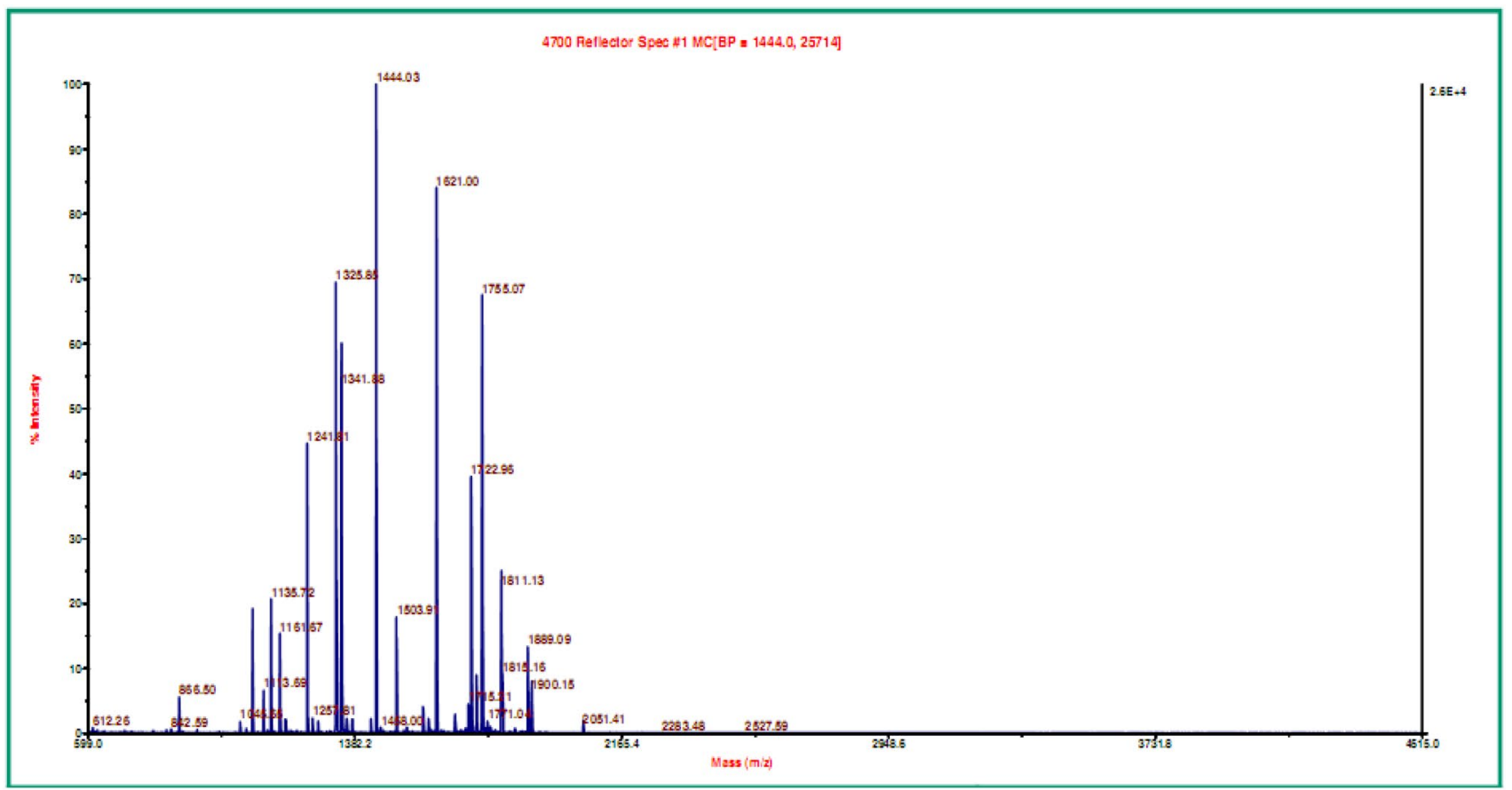

Fig. 3 Peptide mass fingerprint of spot-1 after tryptic digestion

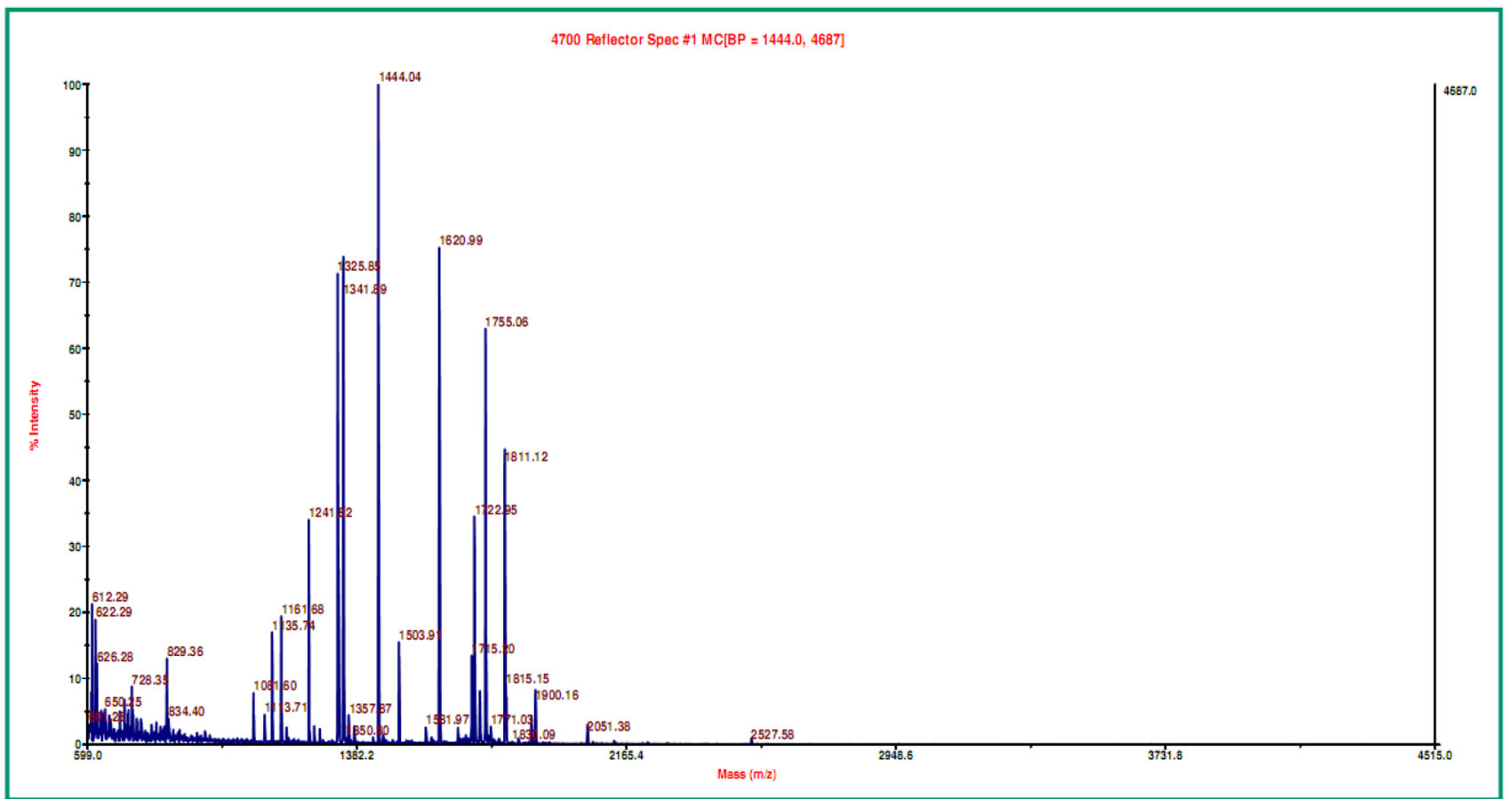

Fig. 4 Peptide mass fingerprint of spot-2 after tryptic digestion 


\section{Discussion}

The Fusobacterium is a genus-containing anaerobic bacteria and comprises of several species, in which $F$. necrophorum is a key human and animal pathogen and is most frequently isolated from necrotic infections [18]. Like other Gramnegative bacteria, outer membrane proteins (OMPs) of $F$. necrophorum are important in facilitating attachment and is the first bacterial component to come in contact with the host cell surface and hence play a vital role in establishment of infection and virulence [19]. OMPs are diverse in nature and play numerous roles such as adhesins, porins, acts as channels for the uptake of nutrients and ions, function as receptors for phages, etc. [11].

In the present study, two immunogenic OMPs from JKS-F3 lktA variant of $F$. necrophorum were identified by MALDI-ToF mass spectrometry. Identification of microbes or its proteins by MALDI-TOF MS is done by either comparing the PMF of unknown organism/protein with the PMFs contained in the database, or by matching the masses of biomarkers of unknown organism with the proteome database [20]. MALDI-ToF MS analysis of $F$. necrophorum OMPs revealed that these are homologous with $43 \mathrm{kDa}$ OMP of F. necrophorum strain $\mathrm{H} 05$, a putative porin on the basis of structure, protein sequence coverage and significant protein score. This putative porin has similar properties as that of other pore-forming proteins of Gram-negative anaerobic bacteria [21]. The predicted 3D structure of this OMP, containing 377 amino acid residues was built in ExPASy swiss-model which showed that it is rich in $\beta$-barrel strands forming channel across the bacterial outer membrane. Porins are a class of immunogens that are membrane-associated integral proteins and form channels which facilitate the diffusion of small water-soluble molecules across bacterial outer membrane and contribute to virulence by interacting with host cells. Porins possess a high proportion of $\beta$-sheet structure, which traverses the membrane in a tightly packed $\beta$-barrel organization. This is in agreement with the findings of [15] who successfully cloned and expressed the $42.4 \mathrm{kDa}$ OMP (fom A gene) from $F$. necrophorum ssp. necrophorum in $E$. coli and showed that it increases the binding of $E$. coli to bovine adrenal gland capillary endothelial (EJG) cells, compared to the un-induced or control vector expressed in E. coli and concluded that the $42.4 \mathrm{kDa}$ OMP serves as an adhesin for endothelial cells for bovine strains of $F$. necrophorum and may play an important role in host colonization and pathogenesis. Similarly [19], studied the OMP profiles of two sub-species of $F$. necrophorum and concluded that sub-species necrophorum and funduliforme had a 40 and $37.5 \mathrm{kDa}$ immunodominant OMP, respectively, which is in agreement with the present findings.

In the present study, identification of two immunogenic OMPs by 2DE-MALDI-ToF/MS from a frequently encountered JKS-F3 lktA variant of $F$. necrophorum adds to the list of potential target antigens and should be of great interest in terms of understanding the host-pathogen interactions. These immunogenic proteins could be exploited for the development of OMP-based recombinant vaccine to mitigate severe foot-rot in sheep and goats.

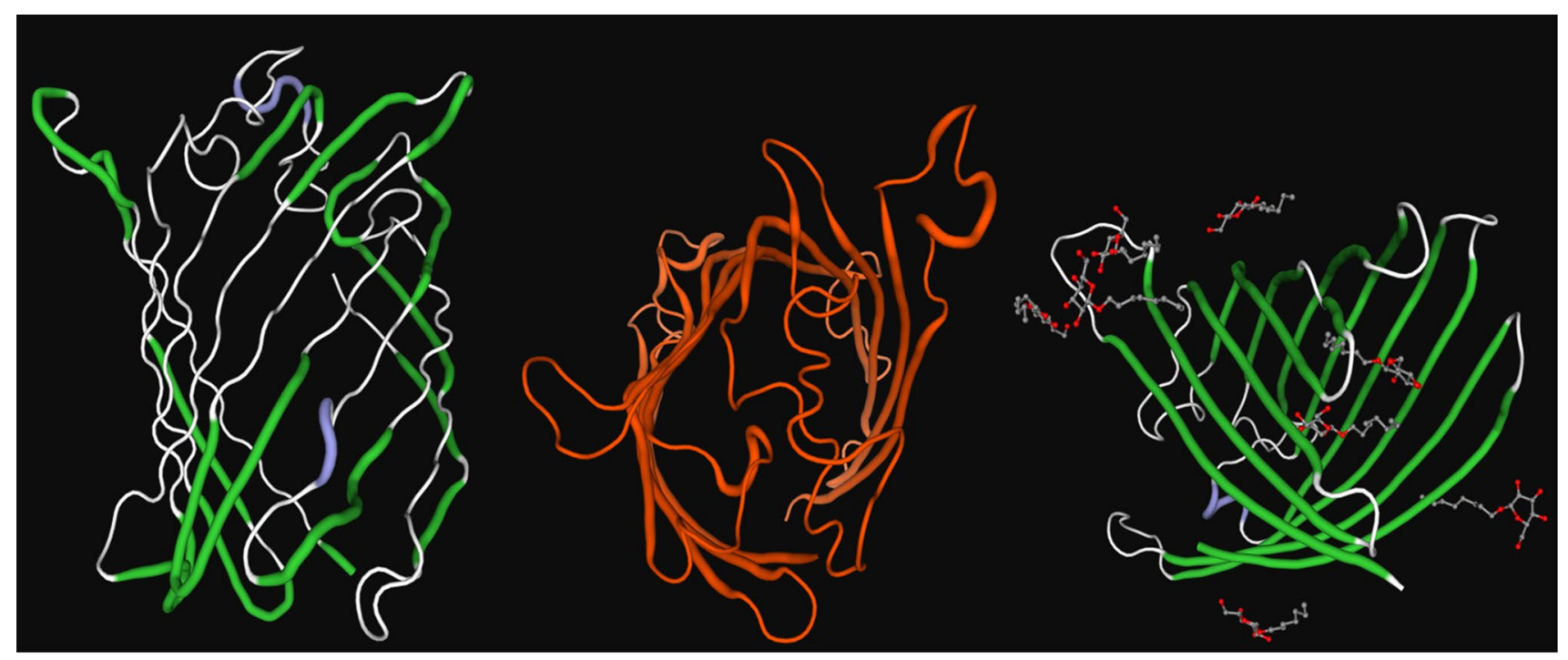

a)

Fig. 5 The predicted 3D structure of $43 \mathrm{kDa}$ OMP (porin) of F. necrophorum strain H05 depicting front (a), top (b) and lateral (c) views, respectively 


\section{Conclusion}

The present investigation identified two immunodominant OMPs from JKS-F3 $l k t A$ variant of $F$. necrophorum. This variant is frequently detected in severe ovine footrot with lesion score 4 indicating that it likely contributes to the severity and duration of the ovine footrot lesions. These immunodominant OMPs could be exploited for the production of OMP-based recombinant vaccine against footrot to mitigate its severity.

Supplementary Information The online version contains supplementary material available at https://doi.org/10.1007/s00284-021-02383-2.

Funding The authors acknowledge the facilities, infrastructure and funds utilized under Niche Area of Excellence (NAE)-ICAR, New Delhi, Grant No. F. No. Edn. 10 (12)/2015-EP and HS.

\section{Compliance with Ethical Standards}

Conflict of Interest The authors declare that there are no conflict of interest.

Ethical Approval This study was performed with the permission of the Institutional Animal Ethics Committees (Number AU/FVS/IAEC14/101-104) of Sher-e-Kashmir University of Agricultural Sciences and Technology of Kashmir, J\&K, India.

Open Access This article is licensed under a Creative Commons Attribution 4.0 International License, which permits use, sharing, adaptation, distribution and reproduction in any medium or format, as long as you give appropriate credit to the original author(s) and the source, provide a link to the Creative Commons licence, and indicate if changes were made. The images or other third party material in this article are included in the article's Creative Commons licence, unless indicated otherwise in a credit line to the material. If material is not included in the article's Creative Commons licence and your intended use is not permitted by statutory regulation or exceeds the permitted use, you will need to obtain permission directly from the copyright holder. To view a copy of this licence, visit http://creativecommons.org/licenses/by/4.0/.

\section{References}

1. Riordan T (2007) Human infection with Fusobacterium necrophorum (Necrobacillosis), with a focus on Lemierre's syndrome. Clin Microbiol Rev 20:622-659

2. Lechtenberg KF, Nagaraja TG, Leipold HW, Chengappa MM (1988) Bacteriological and histological studies of hepatic abscesses in cattle. Am J Vet Res 49:58-62

3. Narayanan S, Nagaraja TG, Okwumabua O, Staats J, Chengappa MM, Oberst RD (1997) Ribotyping to compare Fusobacterium necrophorum isolates from bovine liver abscesses, ruminal walls and ruminal contents. Appl Environ Microbiol 63:4671-4678

4. Nagaraja TG, Chengappa MM (1998) Liver abscesses in feedlot cattle: a review. J Anim Sci 76:287-298

5. Witcomb LA, Green LE, Kaler J, Ul-Hassan A, Calvo-Bado LA, Medley GF, Grogono-Thomas R, Wellington EMH (2014)
A longitudinal study of the role of Dichelobacter nodosus and Fusobacterium necrophorum load in initiation and severity of footrot in sheep. Prev Vet Med 115(1-2):48-55

6. Farooq S, Wani SA, Hassan MN, Aalamgeer S, Kashoo ZA, Magray SN, Bhat MA (2018) The detection and prevalence of leukotoxin gene variant strains of Fusobacterium necrophorum in footrot lesions of sheep in Kashmir, India. Anaerobe 51:36-41

7. Sara F, Konig U, Nymand AK, Pringled M, Aspan A (2015) Characterisation of Dichelobacter nodosus and detection of Fusobacterium necrophorum and Treponema spp. in sheep with different clinical manifestations of footrot. Vet Microbiol 179:82-90

8. Roberts DS, Egerton JR (1969) The aetiology and pathogenesis of ovine foot-rot II. The pathogenic association of Fusiformis nodosus and F. necrophorus. J Comp Pathol 79:217-227

9. Dewhirst FE, Paster BJ, Lafontaine S, Rood JI (1990) Transfer of Kingellaindologens (Snell and Lapage, 1976) to the genus Sutonellagen. nov. as Sutonella indologens comb. nov.: transfer to Bacteroides nodosus (Beveridge, 1941) to the genus Dichelobacter gen. nov. as Dichelobacternodosus comb. nov. Int J Syst Bacteriol 43:426-433

10. Farooq S, Wani SA, Hassan MN, Nazir N, Nyrah QJ (2015) The detection of Dichelobacter nodosus and Fusobacterium necrophorum from ovine footrot in Kashmir, India. Anaerobe 35:41-43

11. Rollauer SE, Sooreshjani MA, Noinaj N, Buchanan SK (2015) Outer membrane protein biogenesis in Gram-negative bacteria. Philos Trans R Soc B 370:20150023

12. Van der Ley M, Struyvé JT (1986) Topology of outer membrane pore protein PhoE of Escherichia coli. Identification of cell surface-exposed amino acids with the aid of monoclonal antibodies. J Biol Chem 261:12222-12225

13. Cowan SW, Schirmer T, Rummel G, Steiert M, Ghosh R, Pauptit RA, Jansonius JN, Rosenbusch JP (1992) Crystal structures explain functional properties of two E. coli porins. Nature 358:727-733

14. Wexler HM (2002) Outer-membrane pore-forming proteins in Gram-negative anaerobic bacteria. Clin Infect Dis 35:S65-S71

15. Menon S, PillaiD K, Narayanan S (2018) Characterization of Fusobacterium necrophorum subsp. necrophorum outer membrane proteins. Anaerobe 50:101-105

16. Zhou H, Bennett G, Hickford JGH (2009) Variation in Fusobacterium necrophorum isolates from sheep, goats and cattle infected with footrot. Vet Microbiol 135:363-367

17. Talwar GP (1983) A handbook of practical immunology. Part II. Vikas Publishing House Pvt Ltd, New Delhi

18. Citron DM (2002) Update on the taxonomy and clinical aspects of the genus Fusobacterium. Clin Infect Dis 35:S22-S27

19. Kumar A, Peterson G, Tiruvoor G, Nagaraja TG, Narayanan SK (2013) Outer membrane proteins of Fusobacteriumnecrophorum subsp.necrophorum and subsp. funduliforme. J Basic Microbiol 00:1-6

20. Singal N, Kumar M, Kanaujia PK, Viridi JS (2015) MALTI-ToF mass spectrometry: an emerging technology for microbial identification and diagnosis. Front Microbiol 6:791

21. Sun DB, Zhang H, Siwen LV, Wang H, Guo DH (2013) Identification of a 43-KDa outer membrane protein of Fusobacterium necrophorum that exhibits similarity with pore-forming proteins of other Fusobacterium species. Res Vet Sci 95(1):27-33

Publisher's Note Springer Nature remains neutral with regard to jurisdictional claims in published maps and institutional affiliations. 